\title{
HIGH SPEED RAIL, EUROPE AND THE CONSTITUTION
}

In light of the controversy that surrounds High Speed 2 ("HS2"), it was predictable that a Supreme Court decision considering the proposal's legality would draw wider interest, however dry and technical the legal questions at issue. Less predictable, perhaps, was that when the decision did appear, as it has done in the form of $R$ (on the application of HS2 Action Alliance Limited) $v$ The Secretary of State for Transport and another [2014] UKSC 3, it would feature dicta that could potentially have much broader constitutional implications.

The Appellants challenged the Government's decision to promote HS2 on two principal grounds. The first was that the Government's decision should have been preceded by a strategic environmental assessment which detailed "the likely significant effects on the environment of implementing” the HS2 project, as well as "reasonable alternatives taking into account the objectives and the geographical scope of the plan or programme” by virtue of EU Directive 2001/42/EC ([2001] OJ 197/30) ("SEA Directive"), articles 4 and 5. The second was that the hybrid bill procedure proposed for the enactment of the Government's proposals, which will include an additional select committee stage in both Houses of Parliament so as to give relevant objectors the chance to be heard, did not comply with the procedural requirements of Directive 2011/92/EU ([2012] OJ L 26/1) (“EIA Directive”), article 6(4), which demands a certain level of effective public participation in the decision making process of any plan or programme likely to have a significant effect on the environment. Underlying both of these claims was an ancillary question as to whether either issue should be referred to the Court of Justice of the European Union (“CJEU”) through the preliminary reference procedure.

The Supreme Court unanimously rejected both the appeal, and the opportunity to refer either issue to the CJEU. The suggestion that a strategic environmental assessment should have been carried out was rejected on the basis that at least one of the preconditions required for such an assessment to be compulsory, namely that the 
document announcing the decision to promote HS2 "set the framework for future development consent” as per article 3(2)(a) of the SEA Directive, was absent. As much as the document in question might be highly influential over any subsequent legislative debate about HS2, their Lordships understood SEA Directive, article 3(2)(a) to have been interpreted so as to require that the DNS not just be influential, but to actually operate as a constraint on Parliament's decision-making process when it came to deciding how to proceed (Lord Carnwath at [38]; Lady Hale at [155]). The Appellants had argued that such a reading would create inconsistency between the SEA Directive and article 7 of the Aarhus Convention, but this was given short shrift by Lord Carnwath (at [50]-[52]).

The issue of whether the proposed hybrid bill procedure was incompatible with the EIA Directive ultimately came down to whether the Directive's objective would still be attained under the modified approach, that being that prior to giving its consent a national legislature gives due consideration to a scheme's environmental impact. If so, the Government would qualify for an exemption from the Directive’s requirements by virtue of EIA Directive, article 1(4). The Court found that the proposed procedure would fulfil the Directive's objectives on the basis that the two conditions laid down by the CJEU-that the legislature's role in the adoption of the scheme must be substantive rather than just formal, and that appropriate information is available to legislative members at the time the proposals are brought forward-were both satisfied. Any draft bill brought forward to gain legislative approval of the HS2 scheme will be actively debated by Parliament before consent is given, and standing orders in both the House of Commons and the House of Lords will ensure that appropriate information pertaining to the proposals is made available to members (Lord Reed at [98]-[99]). An alternative interpretation of the Directives requirements based on opinions of Advocate Generals Sharpston and Kokott which the Applicants had suggested required the Court to conduct a much more intrusive review of the legislative process, effectively amounting to a qualitative judgment as to its merits, was rejected. 
In other circumstances their Lordships might have left it at that. However, seemingly motivated by concerns over the CJEU's interpretative approach to the two Directives, Lords Neuberger and Mance offered some observations on what might have happened had the case before them been a little different. Of most interest for present purposes is what they had to say about the approach the Supreme Court might have adopted had they been required to scrutinise the legislative process in a similar way to that suggested by the Appellants and the two Advocate Generals. This might have created a particular problem in the context of the United Kingdom ("UK”), as it may have conflicted with an important, if not fundamental, aspect of the UK constitution: Article 9 of the Bill of Rights 1689. Under Article 9, 'the freedom of speech and debates or proceedings in Parliament ought not to be impeached or questioned in any court or place out of Parliament', and therefore the extent to which the judiciary can scrutinise Parliament's internal workings is conventionally understood to be severely limited. Perhaps there is a way in which Article 9 can be understood to permit judicial inquiry into the information placed before Parliament to an extent necessary to comply with a more expansive interpretation of the EIA Directive's requirements, by, for instance, adopting a similar approach to that taken in Bank Mellat v Her Majesty's Treasury (No 2) [2013] UKSC 39, [2013] 3 W.L.R. 179. But, if not, does European Union Law reign supreme when it comes into conflict with what is generally perceived as a fundamental aspect of the UK constitution?

Though no definitive answer to this question was given, what is clear from the Supreme Court's judgment is that the answer is a matter of domestic as opposed to European Union law, to be determined by the domestic courts. Moreover, for two reasons the answer is not found by merely applying $R . v$ Secretary of State for Transport, ex p Factortame Ltd (No 2) [1991] 1 A.C. 603. First, because, as Lord Reed concluded, Factortame concerned a conflict between substantive provisions of directly effective European Union law and domestic law, whereas in the present case the conflict would be between procedural requirements of European Union law and domestic law (at [79]). Second, because, according to Lords Neuberger and Mance, Factortame concerned a potential conflict between directly effective European Union law and an ordinary statute, whereas in the present case the conflict would be between 
directly effective European Union law and a constitutional statute, constitutional instrument, or constitutional principle (at [207]-[208]).

For a long time, the lack of a formally enacted constitution in the United Kingdom ensured that the notion of domestic constitutional limits constraining either Parliament or the European Union was largely downplayed. More recently, of course, it has become increasingly common to suggest varying types of limit now exist following the rise of ideas such as common law constitutional rights, and judicial statements such as those contained in $R$. (on the application of Jackson) v Attorney General [2005] UKHL 56, [2006] 1 A.C. 262 and AXA General Insurance Ltd v Lord Advocate [2011] UKSC 46, [2012] 1 A.C. 868. The judgment of Lords Neuberger and Mance might be understood as furthering this claim by adding support to the idea that domestic law recognises certain law as being "constitutional” in nature, whether it be grounded in common law or statute, and that this law is harder to displace. It will be remembered that a similar claim was made in Thoburn $v$ Sunderland City Council [2002] EWHC 195 (Admin), [2003] Q.B. 151, when Laws LJ suggested that a category of constitutional statutes now existed which are immune from implied repeal. Before rushing into any extravagant claims about how the existence of this special category has now been confirmed, however, it might be prudent to note that pigeonholing certain aspects of our law as constitutional may well only serve to create an unnecessary layer of formalism when focus should instead be on the fundamental nature of any dispute.

On the face of it, this case might seem constitutionally insignificant. However, a closer examination of the dicta illustrates a shift in UK constitutional law, from a focus on rules towards a more flexible approach. Article 9 of the Bill of Rights may be best approached through an assessment of whether the courts are questioning the authority of Parliament, as opposed to determining if a matter is a 'proceeding in Parliament' to which courts can pay no regard. There would appear to be no rule of domestic law that directly effective European Union law always overrides national law. Instead, courts should look carefully at the nature of the conflict between the two, evaluating the different constitutional principles engaged. Courts should not 
determine whether a statute is 'constitutional', and therefore cannot be impliedly repealed, but rather evaluate the relative worth of any principles affected, constitutional or otherwise. This approach is to be welcomed, as it will ensure that the courts focus on the merits of any argument put forward when attempting to resolve complex constitutional issues, rather than paying excessive regard to rigid rules. 